УДК 373.5:37.01-053.6

DOI:

Світлана Кирилюк, кандидат педагогічних наук, докторант Інституту проблем виховання НАПН Украӥни

Наталія Бендерець, кандидат педагогічних наук, ректор Комунального навчального закладу Київської обласної ради “Київський обласний інститут післядипломної освіти педагогічних кадрів"

Наталія Примаченко, кандидат педагогічних наук Дрогобииький державний педагогічний університет імені Івана Франка

\title{
ЗНАЧЕННЯ ПОЗАКЛАСНОЇ РОБОТИ З ФІНАНСОВОЇ ГРАМОТНОСТІ ДЛЯ ФОРМУВАННЯ СОЦІАЛЬНОЇ АКТИВНОСТІ УЧНІВ
}

У статті розкриті особливості формування фінансової грамотності та соиіальної активності учнів у закладах загальної середньої освіти. Авторами обтрунтовується необхідність проведення заходів з фінансового виховання у позаурочній та позакласній діяльності. Акцентується увага на фінансовій грамотності як складовій сочіальної активності особистості. Описуються зміст, методи та технологіі проведення заходів з формування фінансової грамотності учнів у закладах загальної середньої освіти.

Ключові слова: фінансова грамотність; соціальна активність; позакласна і позаурочна діяльність; виховні заходи; партнерська взаємодія; технології.

תim. 5.

Svitlana Kyrylyuk, Ph.D.(Pedagogy), Doctoral Student at the Institute for Education Problems of the National Academy of Pedagogical Sciences of Ukraine

Natalia Benderets, Ph.D.(Pedagogy), Rector of the Municipal Educational Institution of the Kyiv Regional Council "Kyiv Regional Institute of Postgraduate Education of Teachers"

Natalia Prymachenko, Ph.D.(Pedagogy) Drohobych Ivan Franko State Pedagogical University

\section{THE IMPORTANCE OF EXTRACURRICULAR WORK ON FINANCIAL LITERACY FOR THE FORMATION OF SOCIAL ACTIVITY OF STUDENTS}

The article reveals the features of the formation of financial literacy and social activity of students in general secondary education. The authors substantiate the need for financial education activities in extracurricular and extracurricular activities. Emphasis is placed on financial literacy as a component of social activity of the individual. The content, methods and technologies of measures for the formation of financial literacy of students in general secondary education are described.

One of the convenient forms of activity, the formation of financial literacy and social activity of students, is extracurricular activities and extracurricular activities. Thanks to clearly planned extracurricular activities for the formation of social activity and financial literacy, students realize what place they occupy in society, learn to solve problems, acquire practical skills to apply them in life situations. They learn not only how to handle money, but also how to and should defend their rights.

In educational institutions, extracurricular activities on financial literacy can be dedicated to the Day of the Financier, Savings Week, subject weeks in social sciences, economics, as well as business games, quizzes, participation in economics competitions, online lessons on financial literacy and economics, conversations. Extracurricular activities also include educational hours, conversations, quizzes, business games, team travel games, online lessons, wall newspapers, drawing and recycling competitions, educational parent meetings on the formation of financial literacy in children. Also, students can conduct research and experiments in the field of economics or other competitions, work on mini-projects, participate in national competitions and tournaments.

Activities aimed at educating the financial and social literacy of schoolchildren can be carried out in various forms. These activities contribute to the formation of the students' general, and at the same time quite holistic ideas about the processes associated with the economy, business, resources and their reasonable consumption, the formation of a successful personality. The formation of financial literacy of students during extracurricular activities is a necessary condition for the education of a socially active person who in modern socio-economic relations can effectively manage their finances, carry out financial planning, make informed and sound financial decisions.

Keywords: financial literacy; social activity; extracurricular and extracurricular activities; educational activities; partnership; technologies.

остановка проблеми. Програми навчання української системи освіти охоплюють практично всі сфери

життєдіяльності сучасної людини, це забезпечує якісну підготовку учнів до дорослого життя Сьогодні додався ще один напрям - практична 


\section{ЗНАЧЕННЯ ПОЗАКЛАСНОЇ РОБОТИ З ФІНАНСОВОЇ ГРАМОТНОСТІ ДЛЯ ФОРМУВАННЯ СОЦАЛЬНОЇ АКТИВНОСТІ УЧНІВ}

підготовка учнів до нинішніх економічних умов, тобто фінансова грамотність дітей.

Навчання фінансової грамотності доцільно починати з початкової ланки освітньої системи, формувати їі протягом тривалого періоду часу на основі принципу “від простого до складного” у процесі повторення й закріплення, спрямованого на практичне застосування знань і навичок. Формування корисних звичок, починаючи 3 раннього віку, допоможе уникнути багатьох помилок протягом дорослішання та набуття фінансової грамотності протягом усього життя.

Сучасні діти є активними споживачами і все більше привертають увагу роздрібних торгових мереж, виробників реклами та банківських послуг. У подібній ситуації брак розуміння й практичних навичок може призвести до необдуманих і необачних вчинків, за які доведеться розплачуватися.

Фінансова грамотність - один 3 основних напрямів освітніх програм, що реалізуються 3 метою вироблення стійких фінансових звичок і правил, які допоможуть уникнути багатьох помилок і небезпек у фінансовій сфері, вчасно навчити поводження з грошима, визначити цілі й пріоритети, допомогти стати соціально активною, успішною особистістю та реалізувати особисті плани [1].

Результати теоретичних досліджень. Основу загальнонаукових, психолого-педагогічних ідей формування соціальної активності та фінансової грамотності становлять теорії та концепції: соціалізаціїособистості (В. Архангельський, Ю. Волкова, А. Капто, В. Кузьмін, Г. Махмадамінова, В. Новицька, О. Олійник, І. Стогній, А. Цабалова та ін.); інноваційних змін освіти на засадах особистісно орієнтованого, розвивального та компетентнісного підходів (І. Бех, Н. Бібік, В. Бондар, I. Бужина, М. Бурда, С. Гончаренко, Т. Гуменникова, М. Свтух, І. Зязюн, В. Кремень, В. Лутай, О. Ляшенко, В. Мадзігон, О. Пєхота, О. Савченко, Н. Щуркова, І. Якіманська та ін.); феномена соціальної активності (І. Бех, Т. Богданова, Ю. Бухалов, Б. Вульфов, О. Зосимовський, Л. Канішевська, В. Коган, Т. Лапіна, В. Мордкович, Т. Мальковська, О. Якуба та ін.); формування фінансової грамотності С. Булавенко, І. Вітенко, О. Губенко, Л. Захаркіна, І. Зубіашвілі, Л. Зюман, Т. Кізима, В. Корнівська, М. Короденко, О. Костюкова, А. Кузнєцова, Г. Кучерова, І. Ломачинська, В. Москаленко, Д. Радзішевська, Т. Смовженко, Т. Терюкова, О. Шпак та ін. [1].

Водночас актуальності набуває дослідження впливу заходів позакласної роботи з фінансової грамотності на формування соціальної активності учнів $33 \mathrm{CO}$.

Метою статті $\epsilon$ визначення ролі позакласної роботи з фінансової грамотності на формування соціальної активності учнівської молоді.

Виклад основного матеріалу. На сучасному етапі впровадження курсу фінансової грамотності в закладах загальної середньої освіти виникає багато питань у зв'язку 3 тим, що предмет вивчення $є$ новим і незвичним. Одне з питань: “Як ввести новий курс: новим уроком, факультативним заняттям або як окремі теми в уже наявних дисциплінах? Які форми діяльності можна застосовувати на етапах формування фінансової грамотності? Які форми проведення заходів варто вибрати?". У більшості закладів освіти немає годин для проведення уроків, факультативів чи гуртків 3 фінансової грамотності, також немає навчальної літератури, але є можливість проводити позакласні заходи.

Тож однією зі зручних форм діяльності 3 формування фінансової грамотності й соціальної активності учнів, є позакласна робота й позаурочна діяльність. Завдяки чітко спланованій позакласній роботі з формування соціальної активності та фінансової грамотності, учні усвідомлюють, яке місце вони займають у соціумі, вчаться долати проблеми, набувають практичних навичок для їх застосування у життєвих ситуаціях. Вони знайомляться не тільки з тим як поводитися з грошима, але й як можна й потрібно відстоювати свої права. В умовах сучасної економіки, у ситуації інфляції завданням 33СО $\epsilon$ навчити дітей правильно оцінювати фінансову ситуацію в постійно змінюваних економічних умовах, не тільки для ведення майбутньої професійної діяльності, а й у межах сім’і [5].

У закладах освіти позакласні заходи 3 фінансової грамотності можна присвячувати Дню фінансиста, Тижню заощаджень, предметним тижням із суспільствознавства, економіки, також це можуть бути ділові ігри, вікторини, участь в олімпіадах з економіки, онлайн-уроки з фінансової грамотності та економіки, бесіди фахівців.

Позакласна робота також включає у себе проведення виховних годин, бесід, вікторин, ділових ігор, командних ігор-подорожей, онлайнуроків, випуск стінгазет, конкурсів малюнків і виробів із вторинної сировини, просвітницьких батьківських зборів на тему формування фінансової грамотності в дітей. Також здобувачі освіти можуть проводити дослідження та експерименти зі сфери економіки в межах МАН чи інших конкурсів, працювати над міні-проєктами, брати участь у всеукраїнських конкурсах та турнірах, зокрема “Стратегія фірми”, які дають їм можливість формувати вміння виконувати різні соціально-економічні ролі. 


\section{ЗНАЧЕННЯ ПОЗАКЛАСНОӤ РОБОТИ 3 ФІНАНСОВОЇ ГРАМОТНОСТІ ДЛЯ ФОРМУВАННЯ СОЦІАЛЬНОЇ АКТИВНОСТІ УЧНІВ}

Гра є природним супутником життя дитини, джерелом радісних емоцій, що приховує велику виховну силу, дає знання й дає змогу спробувати себе в різних ролях. Саме в дитячому віці закладаються основи соціально активної особистості, яка виявляє інтерес до соціуму, фінансових відносин, самостійності, поваги до себе, оточення, своїх батьків й інші цінні якості. Ділові ігри формують у дітей зацікавлене, стійке, шанобливе ставлення до економіки рідної країни, створюють емоційну основу для розвитку патріотичних почуттів, причетності до проблем свого народу. Реалізація циклу ділових ігор з основ фінансової грамотностіце навчання школярів необхідних знань, які знадобляться їм протягом усього життя [1].

Прищеплення інтересу дітей до сфери фінансів $\epsilon$ надзвичайно важливим у зв'язку з нестабільним економічним становищем як у країні, так і в світі загалом. Грамотно організовані ділові ігри добре впливають на фінансовий розвиток і зміцнення економічних знань, логічного мислення, на формування власної думки, побудови своєї концепції як фундаменту фінансової основи [5].

Наведемо приклад окремих виховних заходів 3 формування фінансової грамотності та соціальної активності учнів. Так, захопливою $є$ ділова гра “Подорож у країну Фінансія" для учнів 5-6-х класів, під час якої учні подорожують по станціях, виконуючи різні завдання, переглядають фрагмент мультфільму “Качині історії” (38 серія), відповідають на питання за змістом, формують групи, беруть участь у бесіді за змістом мультфільму, визначають проблему, тему і мету заняття, грають у гру “Розсипалися букви”, розгадують загадки про фінанси й кросворд "Грошові одиниці", відповідають на запитання бліцтурніру та збирають пазли “Збери монети”.

Ділова гра “Живи за власними коштами” (для учнів 9-11-х класів) сприяє підвищенню інтересу до фінансової грамотності. Під час гри старшокласники могли не лише розіграти й порівняти ситуації з різним рівнем доходу, а й “вжитися” у запропоновані соціальні ролі, які були об'єднані між собою в ігрових турах, в єдиний сценарій. Учні також вчилися правильно розподіляти загальний сімейний бюджет. У грі брали участь три команди (з низьким, середнім і високим рівнем доходу). В командах учні самі розподіляли між собою соціальні ролі.

Учні виконували такі завдання:

1. Зібрати продуктовий кошик (з урахуванням рівня доходу сім'і).

2. Розподілити кошти на комунальні послуги (на вибір надані: оренда квартири, квартира в особистій власності й заміський будинок).
3. Відкласти гроші на “Здоров'я” (для сім’ї 3 низьким доходом - захворіла бабуся, із середнім доходом - мама потребує лікування, з високим доходом - на дитину чекає операція).

4. Розрахувати гроші на освіту (для сім'ї $з$ низьким рівнем доходу - зібрати дитину до школи, із середнім доходом - можливість індивідуального навчання, 3 високим доходом - вибір закладу освіти);

5. Скласти бізнес-проєкт.

6. Вибрати банк для вкладення грошових коштів.

7. Можливість зайнятися підприємницькою діяльністю для додаткового заробітку.

8. Взяти участь у лотереї.

Підвищенню інтересу до фінансової сфери сприяють екскурсії до банку. Так, працівники Приватбанку завжди відгукуються і пропонують провести заняття з учнями в позаурочний час. Після таких екскурсій, щоб закріпити пробуджений в учнів до фінансової сфери інтерес, варто провести якусь ділову гру, пов'язану 3 банківською чи іншою економічною діяльністю.

Наприклад, учням 8-9-х класів сподобалася ділова гра: "Банки і банківські продукти”. Метою гри є: знайомство з банківської сферою, історія виникнення грошей, банківські послуги й можливості. За умовами гри необхідно виконати домашнє завдання: виготовити рекламний плакат банку.

Ділова гра має такі етапи:

1. Назва банку (дати назву банку, в якому повинні бути присутніми початкові літери прізвищ команди).

2. Розминка (фінансова вікторина. У кожному етапі бере участь представник команди: перший етап - доповнити фінансовий вірш відповідною римою, другий - вставити слово в фінансове прислів'я, третій етап - згадати, якими монетами користувалися герої відомих літературних творів, художніх та мультиплікаційних фільмів).

3. Мистецтво володіння домашнім господарством (представники команд вибирають собі соціальну роль, методом жеребкування визначають рівень заробітку, після чого показують діяльність родини)

4. Банківські послуги (командам необхідно провести рекламу свого банку та назвати послуги, які він надає).

5. Пінг-понг (команди ставлять один одному запитання зі сфери фінансів).

Наведемо приклад ще однієї інтерактивної гри “Банкноти. Про що можуть розповісти купюри”, яка проводиться з метою профілактики фінансової безграмотності в поводженні з українськими 


\section{ЗНАЧЕННЯ ПОЗАКЛАСНОӤ РОБОТИ З ФІНАНСОВОЇ ГРАМОТНОСТІ ДЛЯ ФОРМУВАННЯ СОЦАЛЬНОЇ АКТИВНОСТІ УЧНІВ}

купюрами. На жаль, не всі школярі знають, що зображено на українських купюрах, і який ступінь захисту мають банкноти. Гра розрахована на учнів 5-того класу з залученням десятикласників як модераторів. Одним із завдань цієї гри $\epsilon$ придумати й намалювати купюру з пам'яткою свого населеного пункту.

Зі старшокласниками в позаурочний час корисно проводити різноманітні тренінги, виховні години та позакласні заходи, спрямовані на формування економічної культури.

Старшокласниками також можуть проводити бесіди з фінансової грамотності з учнями молодших класів. Такі заходи включають ігрові моменти, сюжети з мультфільмів, сценки. Інформація викладається в доступній формі, відповідає віку. Так, для пояснення поняття “бартер" старшокласники інсценували байку Крилова "Ворона і лисиця".

Соціальне партнерство має на увазі залучення до процесу виховання фінансової грамотності працівників фінансової сфери, підприємницької та батьківської громадськості [2]. У межах Дня Фінансиста й Тижня заощаджень варто запросити фахівців, які проведуть бесіди чи ігри. Також можна провести вікторини, конкурси малюнків, виробів з вторинної сировини.

Варто зазначити, що до проведення тижня фінансової грамотності, потрібно залучати всіх учнів освітнього закладу. Наприклад, програма такого тижня може включати:

1. Перегляд освітньої програми Приватбанку “Азбука грошей” учнями 3-6-х класів.

2. Позакласний захід для учнів 6-7-х класів "Професія фінансиста".

3. Конкурс проєктів (презентацій) учнів 8-11-х класів "Мій бізнес-проект".

4. Відкритий урок в 10-му класі “Цінні папери”.

5. Відкрита виховна година у 9-му класі “Податки і платники податків".

6. Вікторина для учнів 5-11 класів “Світова економіка і міжнародні фінанси".

7. Інтегрований урок у 10-му класі “Вступ в фінансову математику".

8. Ділова гра для 5-7-х класів "Подорож в країну Фінансія".

9. Тренінг “Фінансова безпека” для учнів 5-х класів.

10. Тренінг для учнів 6-х класів “Мій бюджет”.

11. Тренінг для учнів 7-х класів "Гроші у нашому житті".

12. Тренінг за програмою НБУ “Фінансова грамотність” для учнів 10-11-х класів.

Виховувати фінансову й соціальну грамотність можна також через інтеграцію в позаурочну діяльність 3 таких предметів, як математика історія, література, географія тощо [1]. Розв'язуючи творчі чи конкурсні завдання, які включають в себе величини ціни, кількості, вартості, учні вчаться теоретично розв'язувати фінансові проблеми. Під час обговорення ситуацій, пов'язаних з літературними творами, в яких згадуються різні соціальні та фінансові ситуації, учням також пропонується висловити власну точку зору, що допоможе сформувати стійке розуміння вибору правильної моделі соціальної й фінансової поведінки.

На сьогоднішній день актуальною $є$ участь учнів у проєктній діяльності. Дослідження, які проводяться на заняттях з фінансової грамотності, а також самостійно, можуть бути представлені у вигляді захисту проєкту на науково-практичній конференції в школі [4]. Величезну роль у формуванні навичок розв'язання соціальних $і$ фінансових завдань $є$ створення великого масового проекту, в якому братимуть участь учні всіх класів та їхні батьки (за бажанням). Її мета - заробляння коштів для допомоги воїнам, онкохворим, ветерану або просто самотній людині похилого віку, кошти на придбання інвалідного візка учениці школи, посильна допомога в будівництві храму в місті або притулку для бездомних собак. Такі соціальні проєкти дають можливість учням відчути впевненість у тому, що вони самі можуть заробляти кошти для реалізації своїх планів та ідей.

Підготовка виховного заходу - це командна діяльність, в якій беруть участь всі учні, батьківська й підприємницька громадськість [3]. У класних колективах обговорюється участь у заході, представлення товару, зробленого своїми руками, обговорення цін на товари, оформлення місця проведення заходу, культурна програма, що супроводжує захід, прибирання необхідного після проведення ярмарки. Завдання розподіляються між усіма учнями. Відбувається розподіл соціальних ролей. У вибраній ролі учні відчувають себе впевнено й отримують моральне задоволення.

У рамках партнерської взаємодії необхідно також налагодити співпрацю вчителів з батьками щодо фінансового виховання дітей. Так, на загальношкільних батьківських зборах проводиться навчання батьків $з$ фінансової грамотності. Адже батьківська допомога $є$ неоціненною у розв'язанні таких питань: як витратити кишенькові гроші, як зібрати на бажаний подарунок, де придбати якісну й недорогу річ, як отримати грошову винагороду за знання (але не за оцінки в щоденнику) або заохочення за ініціативу в допомозі у різних справах [1]. 


\section{ЗНАЧЕННЯ ПОЗАКЛАСНОЇ РОБОТИ З ФІНАНСОВОЇ ГРАМОТНОСТІ ДЛЯ ФОРМУВАННЯ СОЦІАЛЬНОЇ АКТИВНОСТІ УЧНІВ}

Тож діяльність, спрямована на виховання фінансової і соціальної грамотності школярів, може бути проведена в різних формах. Ці заходи сприяють формуванню в учнів загальних, водночас досить цілісних уявлень про процеси, пов'язані з економікою, бізнесом, ресурсами та їх розумним споживанням, формуванню успішної особистості.

Висновок. Таким чином, можна зробити загальний висновок про те, що формування фінансової грамотності учнів під час позакласної роботи є необхідною умовою для виховання соціально активної особистості, яка в сучасних соціально-економічних відносинах зможе ефективно управляти власними фінансами, здійснювати фінансове планування, приймати виважені й обгрунтовані фінансові рішення.

\section{ЛІТЕРАТУРА}

1. Булавенко С.Д., Шпак О.Т., Бабяк М.М., Терес В.І. Формування фінансової грамотності учнів : навч.-метод. посіб. Дрогобич: Видавничий відділ Дрогобицького державного педагогічного університету імені Івана Франка, 2017. 478 с.

2. Зеленцова А., Блискавка Е. Повышение финансовой грамотности населения. Международный опыт и российская практика. Москва : Кнорус, 2012. $112 \mathrm{c}$.

3. Кізима Т. Фінансова грамотність населення: зарубіжний досвід і вітчизняні реалії. Вісник Тернопільського національного економічного університету. 2012. Вип. 2. С. 64-71.

4. Кузина О. Финансовая грамотность и финансовая компетентность: определение, методики измерения и результаты анализа в России. Bonpocы экономики. 2015. № 8. С. 129-148.

5. Фінансова грамотність : підручник / авт. кол. за ред. д-ра екон. наук, проф. Т.С. Смовженко. Київ : УБСНБУ, 2014. 316 с.

\section{REFERENCES}

1. Bulavenko, S.D., Shpak, O.T., Babyak, M.M. \& Teres, V.I. (2017). Formuvannia finansovoi hramotnosti uchniv [Forming students financial literacy]. Drohobych 478 p. [in Ukrainian].

2. Zelentsova, A. \& Blyskavka, E. (2012). Povyshenie finansovoy gramotnosti naseleniya. Meahdunarodnyy opyt i rossiyskaya praktika [Increasing the financial literacy of the population. International experience and Russian practice]. Moscov, 112 p. [in Russian].

3. Kizyma, T. (2012). Finansova hramotnist naselennia: zarubizhnyi dosvid i vitchyzniani realii [Financial literacy of the population: foreign experience and domestic realities]. Bulletin of Ternopil National Economic University, no. 2, pp. 64-71. [in Ukrainian].

4. Kuzinna, O. (2015). Finansovaya gramotnost i finansovaya kompetentnost: opredelenie, metodiki, izmereniya i resultaty analiza $\mathrm{v}$ Rossii [Financial Literacy and Financial Competence: Definition, Measurement Techniques and Analysis Results in Russia]. Economic Issues, no. 8, pp. 129-148. [in Russian].

5. Smovzhenko, T. (2014). Finansova hramotnist [Financial Literacy]. Kyiv, 316 p. [in Ukrainian].

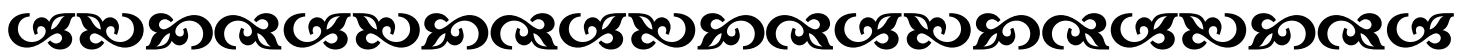

"Велика безодня сама людина, волосинқи ї̈легше полічити, ніж почуття та порухи ï̈ серия”.

"Не виходь у світ, а повертайся до самого себе: всередині людини знаходиться правда".

“Хто шукає - не помиляється".

Аврелій Августин Блаженний

християнський теолог і иерковний діяч

"Ми не можемо творити великі справи - а тільки маленькі справи з велиқою юбв'ю”.

Maтip TТереза

қатолищьқа черниия, засновниия Ордену милосердя

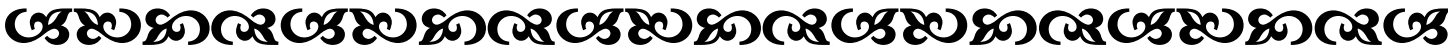

Молодь і ринок №2 (188), 2021 